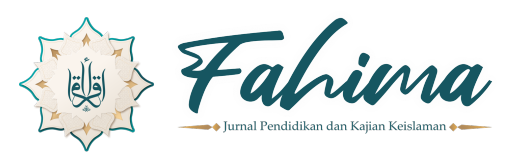

Fahima: Jurnal Pendidikan dan Kajian Keislaman

E-ISSN: 2808-4349 | P-ISSN: 2808-747X | Volume 1 No. 1 Januari 2022

\title{
PENGARUH KECERDASAN LINGUISTIK DAN MINAT BELAJAR TERHADAP KETERAMPILAN MENYIMAK BERITA
}

\author{
${\text { Dyah Widhiarsi }{ }^{*} \text {, Sugiyo }}^{2}$ \\ ${ }^{1}$ SD Islam Al-Hilal, Sukoharjo, Indonesia. \\ 2 Universitas Negeri Semarang, Semarang, Indonesia. \\ * Surel Penulis Koresponden: dyah.widhiarsi@gmail.com
}

\begin{tabular}{|l|l|l|l|}
\hline \multicolumn{4}{|c|}{ Riwayat Artikel } \\
\hline Dikirim: 5/11/2021 & Ditinjau: $18 / 11 / 2021$ & Diperbaiki: $11 / 12 / 2021$ & Diterima: 27/12/2021 \\
\hline
\end{tabular}

\begin{abstract}
Abstrak
Tujuan penelitian ini adalah untuk mengetahui 1) pengarub kecerdasan linguistik terhadap keterampilan menyimak berita; 2) pengaruh minat belajar terhadap keterampilan menyimak berita; 3) pengaruh kecerdasan linguistik dan minat belajar terhadap keterampilan menyimak berita.

Metode yang digunakan dalam penelitian ini adalah metode korelasional ekspostfacto. Populasi penelitian adalah seluruh siswa SMP IT Al-Anis Sukoharjo Tahun Pelajaran 2020/2021. Sampel penelitian sebagian siswa SMP IT Al-Anis Sukoharjo yang diambil dengan simple random sampling. Teknik Pengumpulan data dilakukan dengan menggunakan dokumentasi dan angket.

Berdasarkan hasil penelitian maka dapat disimpulkan 1) pengaruh kecerdasan linguistik terhadap keterampilan menyimak berita pada siswa SMP IT Al Anis Kartasura Sukoharjo Tabun Pelajaran 2020/2021 adalah positif dan signifikan. Artinya jika siswa memiliki tingkat kecerdasan linguistik tinggi maka dapat meningkatan keterampilan menyimak berita dengan baik; 2) pengarub minat belajar terhadap keterampilan menyimak berita pada siswa SMP IT Al Anis Kartasura Sukoharjo Tahun Pelajaran 2020/2021 adalah positif dan signifikan. Artinya jika siswa memiliki minat belajar tinggi maka keterampilan menyimak berita siswa juga baik; 3) ada pengaruh kecerdasan linguistik dan minat belajar siswa terhadap keterampilan menyimak berita pada siswa SMP IT Al Anis Kartasura Sukoharjo Tahun Pelajaran 2020/2021 yang berarti telab terbukti adanya korelasi antara kecerdasan linguistik dan minat belajar (variabel independen) dengan keterampilan menyimak berita (variabel dependen).
\end{abstract}

Kata Kunci: keterampilan menyimak berita, kecerdasan linguistik, minat belajar 


\begin{abstract}
The purpose of this study was to determine 1) the effect of linguistic intelligence on news listening skills; 2) the effect of interest in learning on news listening skills; 3) the influence of linguistic intelligence and interest in learning on news listening skills.

A research method is the expostfacto correlation method. The research population was all SMP IT Al-Anis Sukoharjo academic year 2020/2021. The research sample is some students of SMP IT Al-Anis Sukoharjo taken by random sampling. Techniques Data collection using documentation and questionnaires.

The results are 1) the influence of linguistic intelligence on news listening skills is positive and significant. It means that if students have a high level of linguistic intelligence, they can improve their listening skills well; 2) the effect of interest in learning on news listening skills is positive and significant. It means that if students have a high interest in learning, the students' news listening skills are also good; 3) there is an influence of linguistic intelligence and students' interest in learning on news listening skills, which means that there has been a correlation between linguistic, intelligence, and interest in learning (independent variable) with news listening skills (dependent variable).
\end{abstract}

Keywords: news listening skills, linguistic intelligence, interest in learning

\title{
A. PENDAHULUAN
}

Bahasa mempunyai peranan penting dalam perkembangan intelektual, sosial, dan emosional siswa. Bahasa adalah alat komunikasi antar anggota masyrakat, berupa lambang bunyi suara yang dihasilkan oleh alat ucap manusia (Keraf, 2004). Melalui bahasa, seseorang mendapatkan informasi penting. Bahasa termasuk kebutuhan utama bagi manusia khususnya alat berkomunikasi, sehingga bahasa diajarkan pada manusia sejak lahir. Keterampilan berbahasa meliputi empat aspek yaitu menyimak, berbicara, membaca, dan menulis. Keempat aspek tersebut sangat berhubungan erat dalam usaha seseorang memperoleh kemampuan berbahasa dengan baik.

Slamet menyatakan keterampilan menyimak merupakan aktivitas atau kegiatan paling awal dilakukan oleh anak manusia bila dilihat dari proses pemerolehan keterampilan bahasa (Slamet, 2014). Sebelum siswa dapat melakukan berbicara, membaca, apalagi menulis, kegiatan menyimaklah yang pertama kali dilakukan. Secara berturut- turut pemerolehan keterampilan bahasa itu pada umumnya dimulai dari menyimak, berbicara, membaca dan terakhir menulis.

Era globalisasi seperti saat ini, sejalan dengan perkembangan ilmu pengetahuan dan teknologi, masyarakat dituntut untuk mampu menyimak berbagai informasi atau berita dengan cepat dan tepat, baik melalui radio, televise, telepon, maupun internet. Berita adalah peristiwa yang dilaporkan wartawan dalam bentuk tulisan yang dimuat di media massa (Ermanto, 2005). Menyimak berita mempunyai banyak manfaat, dengan menyimak berita siswa 
dapat memperoleh informasi yang diterimanya. Oleh karena itu, kegiatan menyimak berita sangat penting untuk dikuasai oleh siswa.

Fenomena yang terjadi menunjukkan bahwa anak remaja saat ini rentan mengalami terjadinya hoax dan juga dapat menjadi oknum penyebaran hoax atau berita bohong. Menurut Alois Wisnuhardana Head of Social Media Management Center dari Kantor Staf Presiden RI, remaja mudah percaya pada hoax karena anak muda memang cenderung emosional. Setiap informasi yang di dengar tidak dicerna terlebih dahulu akan langsung disebarkan (Kurniawati, 2021). Berita hoax atau bohong seringkali berdampak langsung pada kehidupan, seperti terjadinya aksi kekerasan antar kelompok atau hancurnya reputasi seseorang atau perusahaan.

Fakta tersebut jelaslah bahwa mencerna suatu berita yang didengar menjadi sebuah keharusan di tengah perkembangan teknologi komunikasi seperti ini, terlebih untuk anak usia remaja. Dalam pembelajaran Bahasa Indonesia di SMP, salah satu kompetensi menyimak yang harus dicapai oleh siswa yaitu mampu menemukan pokok-pokok berita yang didengar atau ditonton melalui radio atau televisi. Adapun indikator yang harus dicapai adalah mampu menemukan pokok-pokok isi berita yang disimak dan mampu menyimpulkan isi berita yang disimak. Dalam pelaksanaannya di sekolah, keterampilan menyimak kurang mendapat perhatian sebagaimana halnya keterampilan berbahasa yang lain. Berdasarkan hasil wawancara dengan beberapa guru kelas VIII SMP IT Al-Anis Kartasura Sukoharjo diperoleh informasi bahwa guru belum secara khusus membelajarkan sekaligus menguji kemampuan menyimak siswa dalam satu periode tertentu,walaupun guru mengetahui bahwa kemampuan menyimak sangat diperlukan untuk mengikuti berbagai pelajaran lainnya.

Keberhasilan pembelajaran menyimak tidak hanya ditentukan oleh factor guru dan media pembelajaran yang digunakan, tetapi juga factor dari dalam diri siswa itu sendiri. Beberapa factor dari dalam diri siswa yang berpengaruh terhadap keterampilan menyimak antara lain, minat belajar dan kecerdasan linguistik. Minat adalah aspek psikologis seseorang yang menampakkan diri dalam beberapa gejala seperti: gairah, keinginan, perasaan suka untuk melakukan proses perubahan tingkah laku melalui berbagai kegiatan yang meliputi mencari pengetahuan dan pengalaman, dengan kata lain minat adalah perhatian, rasa suka, ketertarikan seseorang terhadap belajar yang ditunjukkan melalui keantusiasan, partisipasi, dan keaktifan belajar. Minat ini besar sekali pengaruhnya terhadap belajar, sebab dengan minat seseorang akan melakukan sesuatu yang diminatinya dalam hal ini adalah kegiatan menyimak (Witherington, 1985). Sebaliknya tanpa minat seseorang tidak mungkin melakukan sesuatu dengan sungguh-sungguh. 
Faktor lain yang mempengaruhi keterampilan menyimak adalah kecerdasan linguistik. Kecerdasan merupakan salah satu factor dari dalam yang mempengaruhi keterampilan menyimak, karena kecerdasan yang dibawa oleh masing-masing individu mempengaruhi proses belajar siswa. Setiap siswa memiliki kecerdasan masing-masing yang harus dikembangkan. Salah satu kecerdasan yang dimiliki siswa adalah keceradasan linguistik. Kecerdasan linguistik adalah kecerdasan dalam mengolah kata atau kemampuan menggunakan kata secara efektif baik secara lisan maupun tertulis (Thomas Armstrong, 2013). Berdasarkan pernyataan terseebut dapat dinyatakan bahwa kecerdasan memegang peranan penting dalam mencapai keberhasilan. Keceradasan siswa dan kemampuan guru mengetahui dan memanfaatkan kecerdasan linguistik akan tumbuh dalam mencapai tujuan pembelajaran, sehingga tercapainya tujuan pembelajaran yang diinginkan sesuai dengan indicator pencapaian.

Pada kenyataannya minat belajar tidak selamanya berbanding lurus dengan kecerdasan siswa. Banyak ditemui siswa dengan kecerdasan linguistik tinggi tetapi tidak memiliki minat belajar yang tinggi juga. Seperti yang terjadi pada siswa di SMP IT Al-Anis. Di sekolah ini siswa dikelompokkan kelasnya beradasarkan tingkat kecerdasan. Siswa yang mempunyai kecerdasan kognitif tinggi biasanya dimasukkan ke kelas A atau kelas unggulan. Siswa yang memiliki kecerdasan kognitif sedang atau rendah maka akan dimasukkan ke kelas B atau C. Berdasarkan wawancara dengan salah satu staff pengajar di SMP IT Al-Anis diketahui bahwa tidak semua siswa yang berada di kelas A memiliki minat belajar yang tinggi juga. Pada saat jam pelajaran berlangsung masih banyak ditemui siswa yang masih asik bermain sendiri, mengobrol dengan teman yang lain, mengabaikan tugas dari guru. Siswa di kelas $B$ atau C yang diisi oleh siswa dengan kecerdasan kognitif lebih rendah, pada saat pembelajaran ada banyak siswa yang memperhatikan penjelasan guru, mengerjakan tugas tepat waktu dan memiliki keterampilan menyimak yang baik pula.

Dari penjelasan di atas terlihat adanya kesenjangan fenomena yang ada. Siswa yang memiliki kecerdasan linguistik tinggi tetapi minat belajarnya rendah hal ini berpengaruh terhadap keterampilan menyimak siswa. Siswa yang memiliki kecerdasan linguistik rendah tetapi memiliki keterampilan menyimak yang lebih baik. Begitupula sebaliknya siswa yang memiliki kecerdasan linguistik tinggi hasil keterampilannya menyimaknya belum tentu juga lebih tinggi. Hal ini menjadi menarik untuk diteliti karena belum ada teori atau penelitian yang benar-benar bisa menjelaskan keterkaitan antara minat belajar dan kecerdasan linguistik terhadap keterampilan menyimak siswa. 


\section{B. METODE PENELITIAN}

Metode penelitian yang digunakan dalam penelitian ini adalah Korelasional ekspost facto. Penelitian ex-post facto meneliti hubungan sebab akibat yang tidak dimanupulasi atau tidak diberi perlakuan oleh peneliti. Adanya hubungan sebab-akibat didasarkan atas kajian teoritis, bahwa sesuatu variable disebabkan atau dilatarbelakangi oleh variable tertentu atau mengakibatkan variable tertentu.

Penelitian ini diawali dengan mengkaji teori-teori dan pengetahuan yang sudah ada sehingga muncul sebab permasalahan. Permasalahan tersebut diuji untuk mengetahui penerimaan atau penolakannya berdasarkan data yang diperoleh dari lapangan. Adapun data yang diperoleh dari lapangan dalam bentuk skor kecerdasan linguistik dan skor minat belajar, serta skor atau nilai keterampilan menyimak berita dalam bentuk angka-angka yang sifatnya kuantitatif.

Populasi dalam penelitian ini adalah seluruh siswa SMP IT Al-Anis Kartasura Tahun Pelajaran 2020/2021 yang berjumlah 200 siswa yang terdiri dari 6 kelas, adapun jumlah siswa tiap angkatan yaitu: kelas 7 sebanyak 60 siswa. Kelas 8 sebanyak 72 siswa dan kelas 8 sebanyak 66 siswa. Anggota populasi akan diambil sebagian untuk disajikan sebagai sampel. Karena populasi yang ada di SMP IT Al-Anis Kartasura berjumlah 200 siswa, maka penulis mengambil sampel siswa kelas VIII dan kelas VII sebanyak 127 siswa. Teknik pengambilan sampel yang digunakan adalah teknik simple random sampling (sampel acak sederhana). Simple random sampling adalah cara pengambilan sampel dengan memilih langsung dari populasi dan besar peluang setiap anggota populasi untuk menjadi sampel sangat besar (Sugiyono, 2016). Penggunaan sample random sampling disebabkan anggota populasi penelitian ini dianggap homogen karena sampel yang diambil adalah siswa tetap yang berada di SMP IT Al-Anis Kartasura Sukoharjo Tahun Pelajaran 2020/2021.

Teknik analisis yang digunakan dalam penelitian ini adalah analisis variansi dua jalan (anava dua jalan) dengan taraf signifikansi $(=0,05)$. Analisis data yang digunakan dalam penelitian ini adalah analisis variansi dua jalan (anava dua jalan) dengan taraf signifikansi $(=0,05)$. Teknik anava digunakan dalam analisis data ini karena dapat dipakai untuk menguji perbedaan dua rerata atau lebih. Teknik analisis data ini digunakan untuk menguji ketiga hipotesis yang telah dikemukakan. Teknik analisis data uji lanjut anava yang digunakan adalah uji Scheffe untuk melihat pengaruh perlakuan yang lebih baik.

Selain anava dua jalan dan uji Scheffe, digunakan pula analisis data lain yaitu uji Lilliefors dan uji Bartlett. Uji Lilliefors dan uji Bartlett digunakan 
untuk menguji prasyarat analisis yaitu normalitas dan homogenitas.

\section{HASIL DAN PEMBAHASAN} berikut:

Berdasarkan hasil analisis data diperoleh hasil penelitian sebagai

Tabel 1. Rangkuman Analisis Variansi Dua Jalan dengan Sel Tak Sama

\begin{tabular}{|l|l|l|l|l|l|l|}
\hline $\begin{array}{l}\text { Sumber } \\
\text { Variasi }\end{array}$ & $\mathbf{J K}$ & $\mathbf{d K}$ & $\mathbf{R K}$ & $\mathbf{F}_{\text {obs }}$ & $\mathbf{F}_{\text {tabel }}$ & $\begin{array}{l}\text { Keputusan } \\
\mathbf{U j i}\end{array}$ \\
\hline $\begin{array}{l}\text { Kecerdasan } \\
\text { Linguistik } \\
\text { (A) }\end{array}$ & 2021,2205 & 1 & 2021,2205 & 21,1057 & 3,931 & $\mathrm{H}_{0}$ ditolak \\
\hline $\begin{array}{l}\text { Minat } \\
\text { Belajar (B) }\end{array}$ & 911,645 & 1 & 911,645 & 9,5194 & 3,931 & $\mathrm{H}_{0}$ ditolak \\
\hline $\begin{array}{l}\text { Interaksi } \\
(\mathrm{AB})\end{array}$ & 413,64 & 1 & 413,64 & 4,3192 & 3,931 & $\mathrm{H}_{0}$ ditolak \\
\hline Galat & 4884,1 & 51 & 95,7667 & & & \\
\hline Total & 8230,61 & 54 & & & & \\
\hline
\end{tabular}

Berpijak pada perhitungan uji hipotesis sebelumnya diketahui bahwa ketiga hipotesis nol ditolak, maka diperlukan uji lanjut yaitu uji komparasi ganda. Uji komparasi ganda dimaksudkan untuk mengetahui perbedaan rerata setiap pasang kolom, setiap pasang baris, dan setiap pasang sel yang secara signifikan berpengaruh terhadap keterampilan menyimak berita. Dalam penelitian ini metode Scheffe digunakan untuk uji komparasi ganda karena sampel yang terpilih memiliki jumlah yang berbeda.

\section{Rerata Nilai Keterampilan Menyimak Berita Masing-Masing Sel}

Tabel 2. Rata-rata Nilai Keterampilan Menyimak Berita Masing-masing Sel

\begin{tabular}{|l|l|l|l|}
\hline \multirow{2}{*}{\multicolumn{1}{|c|}{ Minat Belajar }} & \multicolumn{2}{|c|}{ Kecerdasan Linguistik } & \multicolumn{1}{c|}{ Rataan } \\
\cline { 2 - 3 } & \multicolumn{1}{|c|}{ Tinggi } & Rendah & \\
\hline Tingginal & 92,67 & 90 & 91,335 \\
\hline Rendah & 86 & 72,31 & 79,155 \\
\hline Rataan Marginal & 89,335 & 81,155 & \\
\hline
\end{tabular}




\section{Column Comparison:}

Tabel 3. Rangkuman Uji Komparasi Rerata Antar Kolom

\begin{tabular}{|c|c|c|l|}
\hline \multicolumn{1}{|c|}{$\mathbf{H}_{\mathbf{0}}$} & $\mathbf{F}_{\text {obs }}$ & $\mathbf{F}_{0,05 ; 1,112}$ & Keputusan Uji \\
\hline$\mu .1=\mu_{.2}$ & 9,5278 & 3,931 & $\mathrm{H}_{0}$ ditolak \\
\hline
\end{tabular}

\section{Row comparison:}

Tabel 4. Rangkuman Uji Komprasi Rerata Antar Baris

\begin{tabular}{|c|c|c|l|}
\hline \multicolumn{1}{|c|}{$\mathbf{H}_{\mathbf{0}}$} & $\mathbf{F}_{\text {obs }}$ & $\mathbf{F}_{\mathbf{0}, 05 ; 1,112}$ & Keputusan Uji \\
\hline$\mu_{.1}=\mu_{.2}$ & 21,293 & 3,931 & $\mathrm{H}_{0}$ ditolak \\
\hline
\end{tabular}

\section{Mean Comparison Between Cells:}

a) Komparasi Rerata Antar Sel pada Kolom yang Sama

Tabel 5. Rangkuman Komparasi Rerata Antar Sel pada Kolom yang Sama

\begin{tabular}{|l|l|l|l|}
\hline \multicolumn{1}{|c|}{$\mathbf{H}_{\mathbf{0}}$} & \multicolumn{1}{c|}{$\mathbf{F}_{\text {obs }}$} & \multicolumn{1}{c|}{$\mathbf{F}_{\mathbf{0}, 05 ; 3,112}$} & \multicolumn{1}{c|}{ Keputusan Uji } \\
\hline$\mu_{11 \text { vs }} \mu_{12}$ & 8,4841 & 8,388 & $\mathrm{H}_{0}$ ditolak \\
\hline$\mu_{21}$ vs $\mu_{22}$ & 20,39 & 8,388 & $\mathrm{H}_{0}$ ditolak \\
\hline
\end{tabular}

b) Komparasi Rerata Antar Sel pada Baris yang Sama

Tabel 6. Rangkuman Komparasi Rerata Antar Sel pada Baris yang Sama

\begin{tabular}{|l|l|l|l|}
\hline \multicolumn{1}{|r|}{$\mathbf{H}_{\mathbf{0}}$} & \multicolumn{1}{|c|}{$\mathbf{F}_{\text {obs }}$} & \multicolumn{1}{|c|}{$\mathbf{F}_{0,05 ; 3,112}$} & \multicolumn{1}{|c|}{ Keputusan $\mathbf{U j i}$} \\
\hline$\mu_{11}$ vs $\mu_{21}$ & 0,4963 & 8,388 & $\mathrm{H}_{0}$ diterima \\
\hline$\mu_{12}$ vs $\mu_{22}$ & 13,7511 & 8,388 & $\mathrm{H}_{0}$ ditolak \\
\hline
\end{tabular}

Hipotesis Pertama:

Hipotesis pertama dalam penelitian ini adalah Keterampilan menyimak berita pada kelompok siswa yang memiliki tingkat kecerdasan tinggi lebih baik daripada kelompok siswa yang memiliki tingkat kcerdasan rendah.

Kecerdasan linguistik siswa dibutuhkan untuk memahami dan menganalisis secara tepat dalam menyimak informasi secara naratif. Dengan adanya kecerdasan linguistik yang dimilikinya, siswa diharapkan 
mampu menghafal, mengingat, memahami informasi, memiliki kepekaan terhadap arti kata dan urutannya, menyampaikan suatu pesan lisan dengan jelas dan runtut, menulis suatu karya, melakukan persuasi dan negosiasi, menggunakan kata dan bahasa secara efektif, serta menyukai dan mahir berdiskusi dan berdebat untuk memperoleh pengalamanpengalaman yang dibutuhkan dalam meningkatkan kemampuan menyimak berita.

Hal tersebut sesuai dengan pendapat Muhibbin Syah bahwa menyimak berita juga memerlukan pemikiran yang sistematis, logis, dan teliti, khususnya dalam informasi berbentuk narasi (Syah, 2012). Di samping itu untuk dapat menyimak informasi berbentuk narasi diperlukan kemampuan dasar seperti kemampuan penalaran untuk dapat menganalisis informasi dengan kemampuan verbal agar dapat mengubah informasi menjadi kalimat sederhana.

\section{Hipotesis Kedua:}

Hipotesis kedua dalam penelitian ini adalah Keterampilan menyimak berita pada kelompok siswa yang mempunyai minat belajar tinggi lebih baik daripada kelompok siswa yang mempunyai minat belajar rendah.

Minat belajar memegang peran yang penting dalam memberikan gairah, semangat, dan rasa senang dalam belajar, sehingga siswa yang mempunyai minat belajar tinggi memiliki energi yang banyak untuk melaksanakan kegiatan pembelajaran. Dengan adanya minat belajar yang tinggi siswa akan merasa senang dan bersemangat pada gilirannya akan mempengaruhi kualitas dari proses pembelajaran dan hasil belajar siswa. Secara sederhana, dengan adanya motivasi akan mendorong siswa untuk belajar dengan senang hati dan bersungguh-sungguh.

Dalam penelitian ini siswa yang mempunyai minat belajar tinggi menunjukkan performa yang baik selama proses pembelajaran. Siswa terlihat aktif dalam mengikuti pelajaran. Begitu juga sebaliknya, siswa yang mempunyai motivasi belajar rendah terlihat kurang bersemangat dalam mengikuti pembelajaran. Mereka terlihat sibuk dengan aktivitas diluar kegiatan pembelajaran. Menurut Suyanto dan Jihad dalam kegiatan pembelajaran, minat dapat dijadikan sebagai keseluruhan daya penggerak di dalam diri siswa yang menimbulkan kegiatan belajar, menjamin kelangsungan kegiatan pembelajaran, dan memberikan arah pembelajaran, sehingga dapat mencapai tujuan dalam proses belajar (Suyanto \& Jihad, 2014). Dengan demikian dapat disimpulkan bahwa minat belajar berpengaruh terhadap keterampilan menulis narasi siswa. 
minat belajar yang dimiliki siswa akan memberikan dorongan dalam kegiatan belajar termasuk belajar menulis narasi.

Hasil penelitian ini sejalan dengan hasil penelitian Al-Shourafa motivasi minat erat hubungannya dengan proses pembelajaran. Pengaruh minat pada proses pembelajaran yaitu bagaimana siswa belajar dan bagaimana siswa memahami materi pembelajaran. Minat mengarahkan perilaku ke arah tujuan tertentu, dan menyebabkan peningkatkan usaha dan energi (Al-Shourafa, 2012). Ini berarti bahwa siswa dengan minat belajar tinggi cenderung mempunyai hasil tulisan yang lebih baik dari pada siswa yang mempunyai motivasi rendah

\section{Hipotesis Ketiga:}

Hasil analisis data menunjukkan bahwa adanya interaksi antara kecerdasan linguistic dan minat belajar terhadap keterampilan menyimak berita siswa.

Hasil penelitian menunjukkan bahwa pada siswa yang memiliki tingkat kecerdasan linguistik tinggi, keterampilan menyimak berita siswa yang memiliki minat belajar tinggi lebih baik daripada siswa yang memiliki minat belajar rendah. Pada siswa yang memiliki tingkat kecerdasan rendah, keterampilan menyimak berita siswa yang mempunyai minat belajar tinggi lebih baik daripada siswa yang memiliki minat belajar rendah. Pada siswa yang memiliki minat belajar tinggi, keterampilan menyimak berita siswa yang memiliki kecerdasan linguistik tinggi lebih baik daripaada siswa yang memiliki tingkat kecerdasan rendah. Pada siswa yang mempunyai motivasi belajar rendah, keterampilan menyimak berita siswa yang memiliki tingkat kecerdasan tinggi sama dengan siswa yang memiliki tingkat kecerdasan rendah.

Berdasarkan hasil penelitian, terdapat perbedaan keterampilan menyimak berita antara siswa yang memiliki tingkat kecerdasan tinggi dan siswa yang memiliki tingkat kecerdasan rendah pada masing-masing kategori minat belajar siswa.

\section{KESIMPULAN}

Berdasarkan hasil uji hipotesis yang dilaksanakan, maka dapat ditarik simpulan:

1. Pengaruh kecerdasan linguistik terhadap keterampilan menyimak berita pada siswa SMP IT Al-Anis Kartasura Sukoharjo adalah positif dan signifikan dikarenakan nilai $t_{\text {hitung }}>\mathrm{t}_{\text {tabel }}(21.106>3.931)$. Artinya jika siswa 
memiliki tingkat kecerdasan linguistik tinggi, maka dapat meningkatkan keterampilan menyimak berita dengan baik.

2. Pengaruh minat belajar terhadap keterampilan menyimak berita siswa SMP IT Al-Anis Kartasura Sukoharjo adalah positif dan signifikan dikarenakan nilai $\mathrm{t}_{\text {hitung }}>\mathrm{t}_{\text {tabel }}(9.5194>3.931)$. Artinya jika siswa memiliki minat belajar yang tinggi maka keterampilan menyimak berita siswa juga baik.

3. Pengaruh kecerdasan linguistik dan minat belajar secara simultan terhadap keterampilan menyimak berita siswa SMP IT AL-Anis Kartasura Sukoharjo terbukti kebenarannya, hal ini dibuktikan dari besarnya thitung $>\mathrm{t}$ tabel $(4,3192>3.931)$ dengan taraf signifikansi 0,05 atau $5 \%$. Berarti kecerdasan linguistik dan minat belajar berpengaruh positif dan signifikan terhadap keterampilan menyimak berita.

Berdasarkan hasil di atas, dapat disimpulkan bahwa keterampilan menyimak berita siswa dipengaruhi oleh kecerdasan linguistik dan minat belajar.

\section{E. REFERENSI}

Al-Shourafa, A. (2012). The Effect of Motivation On Jordanian 5th Grade Students Writing Skill in English. European Scientific Journal, 8(22).

Ermanto. (2005). Wawasan Jurnalistik Praktis (cet. 1). Cinta Pena.

Keraf, G. (2004). Komposisi: Sebuab pengantar kemahiran bahasa / oleb Gorys Keraf (Cet . ke-7). Nusa Indah.

Kurniawati, N. (2021, Januari 5). Berkembangnya Hoaks di Kalangan Remaja. KOMPASIANA.

https://www.kompasiana.com/nandakurniawati/5ff4806a8ede484c3 c182272/berkembangnya-hoax-di-kalangan-remaja

Slamet, S. Y. (2014). Pembelajaran bahasa dan sastra Indonesia di kelas rendah dan kelas tinggi sekolah dasar. Sebelas Maret University Press.

Sugiyono. (2016). Metode Penelitian Kombinasi (Mixed Methods). CV. Alfabeta.

Suyanto \& Jihad. (2014). Menjadi Guru Profesional Strategi Meningkatkan Kualifikasi dan Kualitas Guru Di Era Global. Esensi.

Syah, M. (2012). Psikologi Belajar. PT. Raja Grafindo Persada.

Thomas Armstrong. (2013). Kecerdasan Multipel di dalam Kelas (Dyah Widya Prabaningrum, Penerj.). Indeks.

Witherington, H. C. (1985). Psikologi pendidikan (M. Buchori, Penerj.). Aksara baru. 